\title{
STYVBARNEN I FOLKHEMMET?
}

\section{UTANFÖRSKAP I SVENSKA BARNDOMS- SKILDRINGAR}

\author{
MAGDALENA $\dot{Z} M U D A-T R Z E B I A T O W S K A$ \\ Adam Mickiewicz University in Poznań
}

ABSTRACT. The subject of the article is the experience of social exclusion present in five contemporary novels on childhood and adolescence spent in the Swedish folkhem, by Jonas Gardell, Lena Andersson, Mikael Niemi, Torbjörn Flygt and Susanna Alakoski. In the first part of the article I am discussing social exclusion as a term used in the debate about the Swedish welfare-state in crisis. The second part is an analysis of the literary texts, using a sociological perspective. I am focusing there on portraits of the children that are main characters in the novels, the children whose personal identity is being shaped in the shadow of the collective dream of a perfect society. Asking a question about the specifically Swedish character of those children's sense of exclusion, I am referring to the words of the social democratic leader Per Albin Hansson, who in his speech of 1928, presented a vision of Sweden as a happy and fair common home (folkhem), in which there is no place for either favored citizens ("darlings"), or for second-class citizens ("stepchildren").

\section{BARNDOMSSKILDRINGAR UR DET SVENSKA FOLKHEMMET}

Romanerna En komikers uppväxt av Johan Gardell (1992), Var det bra så? av Lena Andersson (1999), Populärmusik från Vittula av Mikael Niemi (2000), Underdog av Torbjörn Flygt (2001) och Svinalängorna av Susanna Alakoski (2006) har barndom och uppväxt som huvudtema. I Anderssons och Alakoskis fall handlar det om debutböcker, för de övriga författarna har böckerna varit en vändpunkt i karriären. Alla romanerna fick ett bra mottagande både från kritikerna och den breda läsekretsen. Flygts, Niemis och Alakoskis böcker belönades respektive år med 
Augustpriset. ${ }^{1}$ Gemensamt för de analyserade romanerna är tydliga självbiografiska inslag: huvudkaraktärerna är i princip jämnåriga med sina skapare och de växer upp i miljöer som motsvarar, påminner om eller är lika med författarnas barndomsmiljöer, såväl $\mathrm{i}$ fråga om geografiskt läge som social placering.

Den tematiska likheten bestämmer inte berättelseformen. I romanerna har det använts olika stilar och tekniker från Anderssons reportageliknande prosa via Alakoskis naturalistiska studie till Niemis magiska realism. Flygt experimenterar med berättandet då han varvar barndomsminnen med långa associationsrika utvikningar som påminner om medvetandeströmmar. Romanerna av Alakoski, Niemi och Flygt berättas i första person. Gardell förflyttar sig mellan två parallella berättelsenivåer: den vuxne berättarens brev till en skolkompis och reminiscenser från barndomen som presenteras i tredje person. En berättare i tredje person förekommer även hos Andersson.

Den analys av romanerna som jag har gjort inom ramen för det pågående forskningsprojektet om folkhemmet som kulturell och mental kategori representerad i den svenska litteraturen har varit inriktad på att belysa deras förankring i den folkhemska verkligheten och den unika blandning av nostalgi och kritiskt avstånd som gör dem till intressanta röster i debatten om den svenska välfärdsstaten. I den föreliggande texten redogör jag för en av trådarna som tydligt har framträtt vid analysen, nämligen erfarenheter av utanförskap som romankaraktärerna får under sin uppväxttid. För att förklara orsaker till och följder av Mattis, Leenas, Juhas, Johans och Lottas utanförskap tillämpar jag det sociologiska perspektivet och jag diskuterar samspelet mellan den personliga identiteten och den kollektiva drömmen om det perfekta samhället. Jag ställer också frågan om det utanförskap som skildras i romanerna kan betraktas som ett universellt problem eller ett fenomen som bär en stark folkhemsk prägel och därför bör tolkas mot bakgrund av Per Albin Hanssons vision av ett samhälle utan kelgrisar och styvbarn.

\section{GEMENSKAP OCH UTANFÖRSKAP}

Begreppet UTANFÖRSKAP är en av i svenskan förekommande översättningar av den engelska termen SOCIAL EXCLUSION som introducerades på 1970-talet ${ }^{2}$ och som har gjort en snabb karriär inom modern psykologi, sociologi och pedagogik samt blivit en del av den politiska diskursen.

${ }^{1}$ Augustpriset är ett av Sveriges mest prestigefulla litterära pris som instiftades 1989 av Svenska Förläggareföreningen. Priset delas ut årligen till de bästa nyutkomna böckerna på svenska i tre kategorier: årets svenska skönlitterära bok, årets svenska fackbok och årets svenska barn- och ungdomsbok (www. http://augustpriset.se/).

2 Tobias Davidsson pekar på att begreppets ursprung är franskt: exlusion sociale och att termen spreds till EU via Fattigdomsprogrammen (Davidsson 2010:153). 
Besläktade begrepp är MARGINALISATION (sv. marginalisering) och SEGREGATION (sv. segregation, segregering) ${ }^{3}$ eller SOCIAL STIGMA (sv. stigmatisering). ${ }^{4}$ Andra möjligheter att översätta social exclusion till svenska är SOCIAL EXKLUDERING, SOCIAL UTESLUTNING eller SOCIAL UTESTÄNGNING (Davidsson 2010:154), den viktiga skillnaden ligger i att begreppen då tycks syfta mer på processen än resultatet och betona agentskapet hos dem som exkluderar. Utanförskap verkar däremot beskriva ett slags tillstånd som den som blivit exkluderad befinner sig i.

Enligt den mest utbredda definitionen avser begreppet utanförskap en situation där en individ känner sig vara utanför en grupp som den önskar tillhöra (Davidsson 2010:150, Ljungqvist \& Hirsch 2009:3, Szarfenberg 2008:21-25). Forskarna lägger märke till den rumsliga metaforen som begreppet inkluderar: orden innanför och utanför associeras med fysisk närvaro eller frånvaro, med rätt att tillträda en avgränsad plats eller tillträdesförbud. Detta väcker i sin tur positiva och negativa konnotationer: de som finns inne kan åtnjuta skydd och trygghet, de som hamnat utanför uppfattas som problematiska. ${ }^{5}$ Därför kan utanförskap betraktas som både följd av och orsak till mobbning eller diskriminering.

Begreppet social exclusion användes i början främst i debatter om social utsatthet till följd av fattigdom men det har snabbt vunnit insteg på olika områden av samhällslivet. Idag har förteckningen av samhällskategorier som är särskilt hotade av exkludering blivit betydligt längre (Szarfenberg 2008:15f.). När begreppet utanförskap introducerades i Sverige syftade det framförallt på arbetslösas och invandrares situation men det fick snabbt en bredare omfattning. 2004 presenterade folkpartiet en rapport, Utanförskapets karta, där det skildrades ett nytt socialt landskap "präglat av utestängning från arbetsmarknaden, bostadssegregation, bidragsberoende, maktlöshet och sårbarhet" (Utanförskapets karta, 2004:2). Rapporten åtföljdes året därpå av integrationsprogrammet Bryt utanförskapet. Därmed blev begreppet en del av den politiska debatten inför valet 2006 där det användes som ett tungt vägande

${ }^{3}$ En omfattande sammanställning av synonymer och antonymer till social exklusion finns i Ryszard Szarfenbergs text som är ett försök till syntetisering av begreppets olika definitioner. (Szarfenberg, 2008:14) .

${ }^{4}$ Begreppet social stigma introducerades av den amerikanske antropologen och sociologen Erving Goffman (Stigma. Notes on the Management of a Spoiled Identity, 1963) som i sin forskning mest fokuserade på mötet mellan en representant av den "normala" majoriteten och en individ som på grund av ett misskrediterande attribut (kroppslig stigma, karaktärsstigma eller gruppstigma) blir av denna majoritet utpekad som konstig, avvikande, "sämre" (jfr. Czykwin 2007:15-21).

5 Davidsson hänvisar till forskningen av Veronika Koller och Paul Davidson som har analyserat användningen av begreppet social exclusion i den brittiska politiska debatten (Davidsson 2010:154). 
argument av den borgerliga koalitionen i deras konfrontation med vänsterblocket. (Davidsson 2010:149-150).

Det nya begreppets slagkraft låg i att det innebar en direkt motsättning till ett av nyckelbegreppen vid beskrivningen av den svenska välfärdsstaten, nämligen gemenskap. Det frekventa användandet av ordet utanförskap kan därför inte bara tolkas som en utmaning mot den dåvarande socialdemokratiska regeringen Persson utan även mot socialdemokraternas samhällsvision som sedan slutet på 1920 talet har varit känt under namnet folkhemstanken.

I namnet folkhemmet som med tiden kommit att omfatta såväl den ideologiska ramen för konstruktion av den socialdemokratiska välfärdsstaten som de praktiska aspekterna av den svenska modellen möts två positivt laddade ord: folk och hem som avser två till synes skilda typer av gemenskap: folkgemenskapen $i$ en modern nationell stat och familjegemenskapen $i$ ett tryggt hem. Flera forskare betonar att folkhemmets dragningskraft har legat just i dess motsägelsefullhet (Berggren \& Trägårdh 2006:231). Mall Stålhammar påpekar $\mathrm{i}$ sin analys av folkhemmet som metafor att föreställningen om landet eller nationen som ett hem hade sedan 1800-talets andra hälft varit väl förankrad i den svenska debatten om behovet av en ny nationell gemenskap. Då denna föreställning fylldes med ett entydigt budskap om jämlikhet och solidaritet, skapades en vision om folkhemmet som visade sig ha en bärande kraft (Stålhammar 1997:95-98). Detta skedde i det så kallade Folkhemstalet från år 1928 där socialdemokraternas ledare och blivande statsminister Per Albin Hansson introducerade det moderna projektet som inom kort (efter valsegern 1932) skulle börja sjösättas av hans parti:

Det goda hemmet känner icke till några privilegierade eller tillbakasatta, inga kelgrisar och inga styvbarn. Där ser icke den ene ner på den andre. Där försöker ingen skaffa sig fördel på andras bekostnad, den starke trycker icke ner och plundrar den svage. I det goda hemmet råder likhet, omtanke, samarbete, hjälpsamhet. (Hansson 1982:227)

Den rumsliga dimensionen har alltid varit en påtaglig del av folkhemsmetaforen men den kom starkast till uttryck i slutet av 1980-talet då visionens osäkra framtid började debatteras i den svenska offentligheten i kölvattnet av den politiska och ekonomiska krisen. Som bevis citerar Stålhammar formuleringar som "folkhemmet demonteras", "folkhemmet rivs" samt en slogan som användes i valrörelsen 1991: "Per Albin byggde folkhemmet. Ingvar Kamprad möblerade det. Ingvar Carlsson släckte ljuset" (Stålhammar 1997:93-94). Insikten att folkhemmet inte längre kan betraktas som en trygg plats att leva på har blivit en utgångspunkt till att uppmärksamma hotet om "vräkning", dvs exkludering ur gemenskapen som resulterar i utanförskap. 


\section{UTANFÖRSKAP I FOLKHEMMET}

Matti, Leena, Juha, Johan och Lotta är huvudpersoner i respektive Populärmusik från Vittula, Svinalängorna, En komikers uppväxt, Underdog och Var det bra så? och alla har i sin barndom och ungdom varit med om situationer som kan benämnas med samlingsbegreppet utanförskap.

Geografiskt sett är karaktärerna spridda från Skåne i söder till Tornedalen i norr. Leena bor i Ystad och Johan i Malmö. Lotta kommer från den fiktiva Stockholmsförorten Stensby, Juha från det fiktiva villasamhället Sävbyholm, nordost om huvudstaden. Mattis hemstad är Pajala beläget i Tornedalen vid Sveriges gräns mot Finland. Miljöerna där handlingen utspelar sig är i flera avseenden typiskt folkhemska. Fridhem i Ystad, Borgmästargården i Malmö och Stensby byggdes inom ramen för miljonprogrammet som skulle lösa den akuta bostadskrisen. Sävbyholm är exempel på den idylliska villaförorten med precis likadana villor i mexitegel, folkhemmets omtyckta fasadmaterial. Vittula-kvarteret i Pajala är en blandning av det gamla och det nya, men också där har moderniteten blivit ett tydligt märkbart inslag $\mathrm{i}$ vardagen.

Tidsmässigt sträcker sig handlingen i romanerna från början av 1960-talet då den femårige Matti tittar på när vägarna i Pajala asfalteras fram till år 1986 då Lotta går sista året $i$ högstadiet och får bevittna hur chockad hennes mor blir över mordet på Olof Palme. ${ }^{6}$ Huvudpersoner i romanerna är vid handlingens början 4-10 år gamla och vi följer deras öden fram till mellanstadiets-, grundskolans- eller gymnasiets-slut. Historiskt sett är 1960talet det andra decenniet av folkhemmets glansperiod då svenskarna skördar frukter av de reformer som har genomförts inom ramen för det stora samhällsprojektet. ${ }^{7}$ Under 1970-talet njuter Sverige fortfarande av sitt rykte att vara ett tryggt välfärdsland och av sin självvalda isolation från omvärlden som tredje-vägen-orienteringen garanterar (Stråth 1992:198-205) men landet står på tröskeln till ekonomiska problem åtföljda av växande skepsis mot politikernas visioner. På 1980-talet är krisen i folkhemmet redan påtaglig och Olof Palmes död betraktas av flera som ett symboliskt slut på det svenska samhällsprojektet. (Hägg 2006:425).

${ }^{6}$ Punkten för handlingens början och skildringens tidsmässiga utsträckning har varit avgörande för den följd som romanerna presenteras i artikelns senare del. Handlingen i Svinalängorna börjar på sommaren 1968, i En komikers uppväxt på nyårsnatten 1969, i Underdog omkring år 1974. Till samma år kan man datera den första scenen i Var det bra så?, men bokens handling utspelar sig huvudsakligen på 1980-talet.

${ }^{7}$ I sin personligt hållna skildring av svensk efterkrigshistoria tillämpar Göran Hägg en mer detaljerad periodisering. Kapitlet som avser perioden 1960-67 betitlas "Från idéer till idyll?" och för "Rekordåren" kallas perioden 1967-1973 - den senare rubriken syftar på den ekonomiska tillväxten (Hägg 2006:161- 233, 237-309). 
I min analys av orsaker till romanfigurernas utanförskap har jag tittat närmare på en rad faktorer som ställs i fokus vid sociologiska undersökningar av problemet och som känns relevanta för barnkaraktärerna i fråga, dvs. etnisk härkomst, tillhörighet till en kulturell eller språklig minoritet, social bakgrund, ekonomiska villkor under uppväxttiden, familjens struktur och relationer mellan barn och föräldrar samt erfarenheter av missbruk, misshandel och mobbning. Jag har koncentrerat mig på de situationer då personerna inser att de står utanför gemenskapen eller medvetandegörs om detta samt sammanhang då utanförskapet tydligast uppträder och då det upplevs som starkast. Olika sätt att hantera sitt utanförskap och de följder som exkluderingen innebär för personernas aktuella och framtida liv har varit en annan viktig punkt i analysen. Den avser för det mesta huvudkaraktärerna men jag har också reflekterat över utanförskapets utbredning i de miljöer som beskrivs i romanerna och relationerna de exkluderade emellan.

\subsection{MATTI}

I författarpresentationen på bokförlagets Norstedts webbplats berättar tornedalingen Mikael Niemi om erfarenheter av kulturmöten som han fått under sin uppväxttid. ${ }^{8}$ Hans första vuxenroman, Populärmusik från Vittula från år 2000 fick svenskarna att öppna ögonen för Tornedalen, den tidigare marginaliserade nordvästra regionen vid svensk-finska gränsen, där finska, samiska och svenska influenser möts $\mathrm{i}$ en unik kulturblandning. Året innan boken publicerades fick tornedalingarna genom riksdagens beslut status som nationell minoritet och deras språk, meänkieli, blev erkänt som ett av fem minoritetsspråk i Sverige. ${ }^{9}$ Romanen som utspelar sig i 1960-talets Pajala bär dock vittnesbörd om en annan tid, då den svenska minoritetspolitiken fortfarande var så när som liktydig med planmässig försvenskning och den tornedalska identiteten ännu var för svag för att tornedalingarna framgångsrikt skulle kunna hävda sin särart.

Huvudkaraktären Matti är vid bokens början 5 år gammal och upplever kulturblandningen som en vanlig del av vardagen. Han har själv ett finskklingande namn liksom de flesta $\mathrm{i}$ släkten, blir inte förvånad att några barn talar finska hemma och kan också växla obehindrat mellan språken: svenskan och byfinskan (meänkieli). När han möter sin blivande bäste vän Niila för första gången ställer Matti frågan "Vad heter du?" på svenska och när den okände pojken inte svarar upprepar han den på finska: "Mikäs sinun nimi on?" (Niemi 2000:16).

8 "Jag föddes 1959 och växte upp i Pajala, alldeles vid den finska gränsen. Min mormor var same och min far är tornedaling. Jag har således rötterna i två kulturer vilket ger mig både kraft och inspiration". (http://www.norstedts.se/Forfattare/Alfabetiskt/N/Mikael-Niemi/)

${ }^{9}$ De övriga nationella minoriteterna i Sverige är judar, romer, samer och sverigefinnar. 
Att tornedalingar inte är som alla andra vanliga svenskar och deras hembygd betraktas som "ett nordligt bihang" till Sverige får Matti veta först när han börjar i skolan (Niemi 2000:49). På ett symboliskt sätt markeras regionens ringa betydelsen i kartboken som barnen använder på geografilektionerna: Skåne är där tryckt i en extra stor och Norra Norrland i en extra liten skala (Niemi 2000:47). Skolprogrammets utformning, läromedel som används i undervisningen och krav som ställs på eleverna hör hemma en helt annan värld, i den syd-och mellansvenska verkligheten, där det finns gott om rådjur, igelkottar, näktergalar, kändisar, trafikljus och slott - allt detta som saknas i Tornedalen (Niemi 2000:49). Det kulturella främlingskapet upplevs på nästan alla områden och genom att jämföra, de mönster som lärs ut i skolan med vardagslivet, iaktta de vuxnas livsöden och bevittna alla förändringar som hembygden genomgår blir barnen allt mer medvetna om att de befinner sig $\mathrm{i}$ underläge:

Vi var inga. Våra föräldrar var inga. Våra förfäder hade betytt noll och intet för den svenska historien. Våra efternamn kunde inte stavas, än mindre uttalas av det fåtal lärarvikarier som sökte sig upp från det riktiga Sverige (...). Vi hade sämsta resultaten på Standardproven i hela riket. Vi hade inget bordskick. Vi hade mössan på oss inomhus. Vi plockade aldrig svamp, undvek grönsaker och hade aldrig kräftskivor. Vi kunde inte konversera, inte deklamera, inte slå in presenter eller hålla tal. Vi gick med tårna utåt. Vi bröt på finska utan att vara finnar, vi bröt på svenska utan att vara svenskar. (Niemi 2000: 49-50)

Det är skolfrökens ansvar att lära barnen ordning och hyfs, att göra små tornedalska vildingar till en del av det svenska samhället. De får antingen acceptera den försvenskning de utsätts för eller finna sig i att de blir förbigångna vid befordran till välfärdsstatens medborgare.

Om en bättre framtid för sina barn drömmer också föräldrarna. Men samtidigt har den äldre generationen utvecklat ett slags försvarsmekanism som yttrar sig i en stundom avvaktande stundom föraktfull attityd till allt det nya som kommer söderifrån. Som "ummikko" - "sydlänning" kan man i Tornedalen knappast räkna med något större anseende (Niemi 2000:67). Och benämningen "knapsu" - "kärringaktig" som syftar på icke-manliga sysslor används också för att beskriva nymodigheter som kommer söderifrån.

Barnen som skildras i Populärmusik från Vittula växer upp i ett identitetsvakuum som finns mellan den främmande och samtidigt lockande majoritetskulturen som tränger sig på och de traditionella vanor och mönster som de fått hemifrån. För Matti och Niila blir rock'n'roll ett alternativ som de nästan desperat klamrar sig fast sig vid. Musiken liknas vid islossningen i Torneälven, den mäktiga och symboliska naturföreteelsen som varje år markerar vårens ankomst. De bryr sig inte om om de är "knapsu" eftersom i den blandidentiteten som de utvecklar får de själva sätta regler för vad som går an. 
Det är viktigt att påpeka att det utanförskap som Matti upplever snarare är av kollektiv än individuell karaktär och inte har något att göra med förhållandena hemma, varken i emotionellt eller materiellt avseende. Hans barndom är trygg, han växer upp i en arbetarfamilj som håller fast vid de tornedalska traditionerna utan att vara alltför konservativ. I fråga om härkomst och social placering liknar familjen sina grannar i kvarteret Vittulajänka som har erfarenheter bakom sig av fattigdom men som kommit sig upp och fått en relativt bra levnadsnivå med egen villa och bil. Fäder i dessa familjer jobbar inom skogs- eller metallindustri, mödrarna är hemmafruar (Niemi 2000:12).

I Niilas fall har utanförskapet mycket djupare grunder. Han kommer från en strängt kristen flerbarnsfamilj, hans fader har en gång varit laestadiansk predikant som sedan gått vilse i sin religiositet och vänt sig mot sina närmaste (Niemi 2000:27-28). Niilas finska moder känner sig mindervärdig och tiger för att hon inte kan svenska, det språk som hon helst skulle vilja lära ut till sina barn. (Niemi 2000:30) Niila växer upp under tystnad i en känslokall miljö med inslag av missbruk och misshandel och hans två utmärkande drag är att han är ovanlig tystlåten och försöker att inte märkas samt att han alltid klöser i små sår som han har på handleden. Han karakteriseras som "en typisk tornedalsk jantevarelse" (Niemi 2000:30-31).

Längtan bort är ett återkommande motiv i berättelsen. Det moderna Sverige hägrar i söder, avlägset och eftersträvat:

Det fanns bara en utväg. En endaste möjlighet om man ville bli någonting, om så det allra minsta. Nämligen att flytta. Vi lärde oss att se fram emot det, övertygade om att det var vår chans i livet, och vi lydde. I Västerås skulle man äntligen bli människa. I Lund. I Södertälje. I Arvika. I Borås. (...) (Niemi 2000:50)

Att flytta söderut betyder dock inte att man automatiskt blir av med stigmat eller att man får det man strävar efter. Det tornedalska kulturbagaget kan visa sig vara en börda som är svår att bära. Av allt att döma har Niila inte orkat bära den, vid bokens slut får vi veta att han är en av dem som kommit hem för att vila på Pajalas kyrkogård. Matti har ett ordnat liv, han är lärare i Sundbyberg och förverkligar sin gamla dröm om att resa till avlägsna platser i världen men även han känner sig splittrad, längtar till Tornedalen och håller på att skriva ner sina barndomsminnen som ska bli till en bok.

\subsection{LEENA}

Huvudpersonen i Svinalängorna heter Leena Moilanen och brukar av kritiker och läsare betraktas som Susanna Alakoskis alter ego (Löfvendahl 2006). Leena är mellanbarnet $i$ en till synes helt vanlig kärnfamilj som vid romanens början får hyra en splitterny lägenhet på Fridhem i Ystad. Moilanens kommer från Finland och har flyttat till Sverige av ekonomiska skäl. Den 
etniska tillhörigheten och familjens sociala placering gör att Leena redan vid starten hamnar i dubbelt underläge, vilket hon i tidig barndom knappt är medveten om. Den sjuåriga flickans glädje över att få bo i en ljus, rymlig lägenhet och tvätta sig i ett riktigt badrum dämpas inte av det som förargar hennes mor, nämligen öknamnet Svinalängorna som bostadsområdet har fătt i folkmun därför att kommunala lägenheter där är avsedda för kategorin "socialfall" (Alakoski 2007:13-20).

Att familjen inte har råd med nya möbler och får nöja sig med begagnade som fadern "fixar" är inte heller något som bekymrar flickan. Det är ingen stor skillnad i levnadsstandard mellan Moilanens och en annan finsk familj som de umgås med och andra jämförelseobjekt saknas. Föräldrarnas framtidsoptimism och förväntningar som de har på det goda landet Sverige, där ingen behöver svälta, "hästarna och kaninerna äter förstklassiga äpplen och morötter" (Alakoski 2007:33) och kommunen betalar bostadsbidrag som ibland är högre än hyran (Alakoski 2007:41) är en annan omständighet som befäster Leena i hennes tro att allt är precis som det ska.

Trots att Leena vid inflyttningen inte kan svenska lyckas hon övervinna språkbarriären mycket fort. Hon lär sig språket "i ett nafs", precis som hennes mor förutspått, genom att leka med Åse, grannflickan på gården. (Alakoski 2007:27f.). Leenas svenskkunskaper blir snart mycket bättre än föräldrarnas, hon börjar lägga märke till de pinsamma fel som fadern gör och rätta dem (Alakoski 2007:63).

Skolan är för Leena en port till en värld av nya möjligheter: hon får vara med i ett simlag, spela flöjt i en orkester, hon kan bli lärare i framtiden om hon är duktig och sköter sig. Samtidigt får hon också en insikt om att det svenska samhället är skiktat och hennes egen familj finns längst ner i den sociala hierarkin. Även grannarna på Fridhem som hör till den lägre arbetarklassen tycks vara en bättre kategori medborgare än Moilanens som aldrig köper nya kläder på Tempo eller Domus utan får begagnade kläder från barnavårdsnämnden eller "snälla tanter", som aldrig äter färdiglagad snabbmat från affären utan "vänder på slantarna" varje gång de handlar livsmedel och som bara kan drömma om att åka bort på semester. Bil, hus eller sommarstuga framstår som helt ouppnåeliga statussymboler. Men det är först och främst födelsedagskalaset hos en klasskompis som bor i en villa med swimmingpool som öppnar Leenas ögon för hur djup klyftan mellan de lyckligt lottade och underklassen är. Hon är förvånad, känner sig besviken, avundsjuk, hon tappar sin barnsliga sorglöshet: "Nä, jag förstod inte varför allting var som det var men jag hade börjat lägga märke till saker på ett annat sätt. Jag åldrades, men det syntes inte i spegeln" (Alakoski 2007:181).

Den tilltagande medvetenheten om att vara dömd till att leva i fattigdom gör att Leena också börjar begripa mer av det som händer runt omkring henne. Föräldrarnas alkoholmissbruk som tidigare kom till uttryck i form av tillfälligt 
festande har med tiden blivit allt grövre och leder till hemmavåld. Nu delas Moilanens liv i nyktra och onyktra perioder och barnens behov träder allt mer i bakgrunden. Leena inser att hon aldrig kommer att bli ett av de barn vars föräldrar bakar bullar till luciadagen, hejar på sina barn vid simbassängen eller arrangerar födelsedagsfester dit hela klassen bjuds. Varje skolavslutning förvandlas till en traumatisk upplevelse för henne för föräldrarna brukar aldrig infinna sig i kyrkan.

Jag ställde mig långt bak i kyrkan, bakom alla andra.

Så liten som möjligt.

Så tyst som möjligt.

Sedan smet jag iväg innan någon skulle se att jag var ensam.

Lika skönt varje gång det var över. (Alakoski 2007:138)

Den skam som Leena känner hindrar henne från att direkt be om hjälp. Istället hoppas hon på att någon märker att hon inte mår bra. Bristen på trygghet som hon lider av i sitt eget hem gör att hon desperat längtar till att bli omhändertagen av det goda samhället. Hon känner att hon börjar förlora fotfästet (Alakoski 2007:185) och sjunker ner i drömmarna om att bli sedd och räddad. (Alakoski 2007:212) Att glömma, "trolla sig bort" från verkligheten blir hennes sätt att uthärda.

Till sin förvåning märker flickan att de som enligt henne skulle ingripa, dvs. socialhjälpen, barnavårdsnämnden och lärarna låtsas att inte märka den farliga utvecklingen och lämnar henne ensam i alla försök att ta hand om den sargade familjen. Den hjälp som familjen får utav staten visar sig ineffektiv och när några mer konkreta åtgärder vidtas har Leena redan tappat sina illusioner och hennes besvikelse över samhället är lika stor som över föräldrarna, vilket kommer till uttryck i de bittert ironiska iakttagelser som hon gör:

När lägenheten var städad, blodet hade koagulerat och Terrie slutat gnälla, gjorde socialkontoret ett planerat spontanbesök i vår svartlistade trappuppgång (...)

Socialtanterna la inte märken till uppgörelserna som låg kvar på sovbordet eller hoten som hängde kvar i luften. De spelade blinda och sa inget om mammas färglada pannkaksblåmärken. De satte sig ner på en av de viktigaste frågorna. (Alakoski 2007:226f.)

Leenas är inte det enda utsatta barnet i Svinalängorna. Familjens framskridande sönderfall sätter en prägel på hennes bröder, varav den äldre, Markku, hamnar i riskzonen för droger och kriminalitet. Fattigdom, våld och missbruk är inslag i flera andra familjers vardag, något som barn vänjer sig vid. Hemma hos Riita är mor alltid nykter, far däremot är full hela tiden. Hemma hos Åse försöker man hålla skenet uppe. Hennes "presentpappa" från Lund som kommer på besök på söndagarna verkar inte bry sig om att dottern blir vittne till moderns alkoholproblem och instabila känsloliv. Att vara 
omringad av andra som delvis delar hennes erfarenheter är viktigt för Leena, när hon umgås med Riita och Åse beter hon sig som andra tonårstjejer: lyssnar på aktuella låtar, snackar om killar, gör framtidsplaner. Den inre solidariteten $\mathrm{i}$ den lilla gruppen är en glimt av hopp i den annars mörka skildringen.

Leenas historia slutar en sommarnatt då tre väninnor smiter hemifrån för att sova över i en koja i skogen. Trots att berättelsen är retrospektiv dyker den vuxne berättaren inte upp $\mathrm{i}$ texten och läsaren får ingen inblick $\mathrm{i}$ huvudkaraktärens fortsatta liv. Frågan om Leena någonsin kommer att ta sig ur utanförskapet måste därför förbli obesvarad. Spekulationer om romanens självbiografiska bakgrund kan betraktas som ett av de möjliga svaren.

\subsection{JUHA}

Juha Lindströms barndomstid som återberättas i En komikers uppväxt infaller på sjuttiotalet, välfärdsstatens sista glansperiod och en tid då man fortfarande hyste den naiva tron att "Sverige var rikast i hela världen och allt utgjorde en del av Guds plan" (Gardell 1992:6). Juha har en finsk mor, en svensk far och en lillasyster Marianne. Läsaren får inte veta något om föräldrarnas bakgrund men man kan gissa att de är uppkomlingar i medelklassen. De gör sitt bästa för att smälta in i den välfärdsidyll som villaförorten Sävbyholm utger sig för att vara. Deras villa i mexitegel liknar alla andra villor i området, de har samma välskötta trädgård som andra grannar, och samma solur som är pricken över i:et, en symbol för den status man uppnått. De hejar på Ingemar Stenmark och gör skidutflykter på vintern. Liksom alla andra föräldrar i Sävbyholm önskar de att Juha ska få plats i tennisskolan för barn och kanske bli en ny Björn Borg (Gardell 1992:31f., 192). Men alla ansträngningar till trots avviker Lindströms från mönstret. Missanpassningens yttre symboler är maskrosor som breder ut sig i trädgården och soluret som gång på gång välter. Tar man en närmare titt på familjelivet ser man att under den vackra ytan slumrar konflikter: föräldrarna skriker och grälar, de är trötta och kanske besvikna på livet, deras tålamod tryter och intresset för barnens problem är bristande (Gardell 1992:18-21). De kan knappast ge sin son det stöd han behöver och verkar inte förstå det han går igenom i sin desperata kamp för att få uppskattning (Gardell 1992:69; 227).

Juhas låga plats i skolhierarkin tycks återspegla familjens osäkra sociala placering. Som halvfinne med föräldrar som röstar på Vpk och ofta handlar mat på krita i närbutiken har han inga chanser att bli en av klassens ledare. Men de etniska och ekonomiska faktorerna är bara en del av förklaringen till varför Juha avviker från de andra barnen. Det är framförallt hans ständiga behov av att vara i centrum, hans konstnärliga natur och förkärlek för bisarra uppträdanden som gör honom till en främmande fågel bland folkhemmets 
standardiserade barn, eller "ett ufo som har landat $i$ den svenska förorten" som den vuxne Juha själv väljer kalla sig för (Gardell 1992:230). ${ }^{10}$

Juha vill helst vara en av dem som respekteras och beundras, han känner sig knappast tillfredsställd med den plats i gruppen som han har, men samtidigt är han mycket mån om att få behålla den. De talrika anpassningsförsök som han gör innebär att han säljer sig själv och deltar i mobbningen av de som rangordnas ännu lägre. Han bjuder inte sin bästa vän Jenny på den "hippa" han arrangerar hemma eftersom Jenny inte passar på fester med sitt fula hårspänne i det stripiga håret. Och han slår klassens hackkyckling Thomas när de två tuffaste killarna befaller honomatt göra det. I förhoppning om att detta hjälper honom att få det erkännande han längtar efter intar Juha rollen som underhållare och clown. Han verkar inte förstå att han på det sättet gör sig ännu märkvärdigare. Den skola som skildras i boken är en arena för brutal uniformering av dem som sticker ut och hänsynslös eliminering av de svagaste som uppnås genom verbal och fysisk misshandel och med lärarnas tysta godkännande. I sitt pendlande mellan den konformistiska önskan att vara med i gruppen och längtan efter att få hitta sitt eget personliga uttryck blir Juha till "en lindansare som kämpat för att hålla balansen, men som till slut, när benen blivit trötta och musklerna stumma, ändå slinter, mister balansen och faller" (Gardell 1992:214).

Jenny och Thomas är två andra barnkaraktärer i romanen som hunsas av sina skolkamrater. Sladdbarnet Jenny har gamla föräldrar och töntiga kläder (Gardell 1992:48-49). Hennes blyghet och låga självkänsla gör att hon inte kan hävda sig i gruppen och därför uppfattas som ful, dum och hopplös. Hon är den som "aldrig vågat någonting $i$ hela sitt liv" (Gardell 1992:121) och hennes överlevnadsstrategi är att finna sig i att vara utsatt. Den udda vänskapen med Juha är hennes stora tröst, därför förlåter hon alla svek från hans sida.

Thomas Karsk har av jämnåriga stämplats som "äcklig" och beroende på situationen ignoreras han eller får stryk. Han har bakom sig en erfarenhet av faderns död och kanske därför försöker han skydda sin mor genom att tiga om att han ständigt är mobbad. Att modern kommer från Tyskland, bryter på svenska och har rykte om sig att inte vara klok i huvudet kan vara en av faktorerna bakom sonens utsatthet. Men det som framförallt gör honom till mobbningsoffer är hans passivitet och oförmåga att säga ifrån som bottnar i den permanent upplevda rädslan (Gardell 1992:145-147). Thomas har inga drömmar och inga framtidsplaner, han vill helst leva hela sitt liv under sängen (Gardell 1992:199). Hans sjunker allt djupare i ensamhet och till sist framstår självmordet som den enda utvägen ur utanförskapet.

${ }^{10}$ Den fristående fortsättningen på En komikers uppväxt heter Ett ufo gör entré. I boken som publicerades år 2001 skildras den tonårige Juhas kamp om att få vara sig själv och hans väg till en ny identitet. 
Juhas relation till Jenny och Thomas avslöjar hans egen rädsla för att bli som dem. För att inte smittas av deras utanförskap försöker han förtränga det medlidande som han hyser för Thomas (Gardell 1992:75) och glömma att han känner sig trygg med Jenny, att hon "är den enda som han aldrig behöver muta" (Gardell 1992:50). Sammanbrottet på skolgården då Juha börjar kasta sten på andra barn resulterar i att han blir utfryst och leder till ett närmande till dem som alltid funnits i underläge. De tar emot honom i sin lilla gemenskap av de utestängda.

Därifrån finns bara ett steg till att medvetet välja en outsiderposition och drömma om att få lämna den skenbara idyllen där alla individuella drömmar mynnar i den kollektiva föreställningen om lyckan. Den drömmen ska Juha uppfylla när han avslutat grundskolan:

Den tionde juni när Juha är femton år ska han stiga på tåget vid Sävbyholms station och lämna Sävbyholm för att aldrig återvända. Med sig har han endast en ryggsäck med tandborste, ombyte för ett par dagar, en radioapparat och boken Best Jokes for Every Occasion .(Gardell 1992:242)

Den vuxne Juhas brev som utgör romanens andra berättarplan kan betraktas som hans uppgörelse med barndomen och ett sent försök att gottgöra sveket mot Jenny och Thomas. ${ }^{11}$ Genom att artikulera deras och sitt eget utanförskap för brevjaget talan för alla dem som avvikit från den folkhemska mallen och som mot alla löften varit dömda att misslyckas.

\subsection{JOHAN}

Torbjörn Flygts roman Underdog är en skildring av en pojkes uppväxt i 1970- och 1980-talets Malmö. Genom att i titeln använda det engelska ordet som från idrottssammanhang och sociologiska analyser av potentiella vinnare och förlorare kom till vardagsspråket för att beteckna en person i underläge som har minimala chanser att lyckas förser han redan $i$ början sin huvudkaraktär med en omisskännlig etikett. ${ }^{12}$

Johan Kraft bor med sin ensamstående mor och en äldre syster i en lägenhet $\mathrm{i}$ ett höghus på Borgmästargården i Malmö. Modern hör till första generationens stadsbor. Hon är vid bokens början anställd på strumpfabriken, men efter uppsägning fattar hon beslutet om att omskola sig och blir löneassistent på Länsstyrelsen, vilket innebär social befordran (Flygt

${ }^{11}$ Den moraliska skulden som tvingar Juha att leta efter den hemska sanningen om vad som hänt hans barndomsvän finns går också som röda tråden genom den tredje delen av Sävbyholmstrilogin - Jenny, publicerad 2006.

12 Den fristående fortsättningen på Underdog som kom ut 2011 har titel Outsider. 
2003:252-255). Hon gör sitt bästa för att ge sina barn en trygg och lycklig uppväxttid. Trots att familjen ständigt brottas med ekonomiska problem är stämningen hemma kärleksfull och barnens kompisar känner sig alltid välkomna att titta in. Bodil Kraft önskar att hennes barn får ett bättre liv än hon själv. Hon är angelägen om att de skaffar utbildning och dottern Monika som är duktigast $\mathrm{i}$ klassen och satsar på medicinstudier är hennes stora hopp.

Johan verkar däremot inte speciellt intresserad av att plugga, i alla fall i grundskolan. Skolan är för honom en förlängning av det umgänge med jämnåriga som börjar på gården. Han är ingen ledartyp, verkar ganska medelmåttig. Han håller sig i bakgrunden i de flesta sammanhang och flyr hellre undan faran än motar bort den. Johan har en relativt svag position i kompisgänget. Hans anpassningsförmåga med drag av konformism gör dock att han inte hotas med att bli utestängd från gruppen. Han är t.ex. den som väljs näst sist $\mathrm{i}$ uttagningen till lagen inför fotbollsmatchen men han är inte bland dem som blir över (Flygt, 2003:16). Underordningsstrategin som han tillämpar i alla konfliktsituationer hjälper honom att klara sig tämligen oskadad men lämnar ofta en känsla av obehag. Som bland annat i konfrontationen med de äldre halvkriminella killarna som med hot och våld lurar till sig pengar av de yngre eleverna på skolgården i högstadiet:

Men du själv då, Johan, vad gör du? Vågar du sätta emot? Nej, du är för feg, du tror att du har bland hårdingarna att göra men när det kommer till kritan är du inget annat än en feg liten skit du är en tyst mes som inget annat vill än att klara dig undan, pissrädd för att få stryk, inga lögner att ta till nu, inga fantasier, inga stories som skyddar dig, du inordnar dig utan motstånd i hierarkin och överräcker själv plånboken till Lundblad för att åtminstone slippa förnedringen att han sliter upp den ur jackan (...) (Flygt 2003:166)

Faderns frånvaro kan betraktas som en av de faktorer som påverkar Johans låga självkänsla. Det är något som skiljer honom från de övriga barnen på gården som är uppväxta i kärnfamiljer. Hans kompisar har sina "farsor" som de respekterar eller skäms för men som finns med som en naturlig del av barndomen. När Johans fader gör ett oväntat insteg i sonens liv bemöts han till en början med blandade känslor men efterhand stiger Johans förväntningar. Det visar sig dock att Folke knappast kan leva upp till dem och att det är för sent att bygga någon djupare relation.

Trots att familjen Kraft inte lever på svältgränsen räcker pengarna sällan till något mer än löpande behov. Barnen är väl medvetna om att valet av det näst bästa, dvs. billigaste alternativet är en nödvändighet när de handlar kläder eller mat, men de har också genomskådat sin mor som säger sig vara nöjd med det hon har: "Monika och jag har fått vänja oss vid att alltid gå ner ett hack, men för oss är morsans nästan-filosofi inte en fråga om vad vi får utan vad vi försakar" (Flygt 2003:164). Om sin status av fattiga släktingar blir syskonen Kraft också påminda varje jul när morbrodern Leif stoltserar med sin goda 
ekonomiska ställning och ger sin son dyra present eller när Johan får ärva kusinen Bernts avlagda kläder.

Det retrospektiva perspektivet som tillämpas i romanen gör det knappast möjligt att sätta en tydlig gräns mellan Johans tämligen sorglösa barndom då han tar familjens sociala ställning som given och den vuxne berättarens fördjupade reflexionen om klyftor som finns i samhället samt chanser och begränsningar som detta för med sig. Den viktiga vändpunkten i huvudkaraktärens liv är utan tvekan gymnasieskolan där sociala skillnader träder fram i all sin bredd. Då börjar Johan komma till insikt om att hans start i livet är betydligt svårare än de kompisars som bor i finare stadsdelar och är födda i förmögna familjer. Plötsligt framstår Borgmästargården som ett slags ghetto vars invånare saknar några framtidsperspektiv. Det som flera andra har fått som ett socialt privilegium måste han själv vinna $\mathrm{i}$ den hårda och långa kampen. Därför utvecklar han en ny strategi och skapar sin nya identitet som ska hjälpa honom att anpassa sig till sin nya miljö och bli av med sina mindervärdeskomplex:

Gymnasium alltså.(...) Jag lär känna andra i klassen, får nya kompisar från Bellevue, Slottstaden och Limhamn, med det bemedlade skiktets diminutiva namnformer: Didde, Jacke, Pirre, Todde, Ludde. Jag bär med mig ett löfte från högstadiet, och kan tack vare känslan av klasslöshet plötsligt slå om och bli nån annan, hänga av mig den tunga ryggsäck som lastas med bakgrund, historia, bristande självkänsla, det är thank you and good bye till den gamle Johan och välkommen i leken till den nye, som kan spela rollen som den han önskar vara. (Flygt 2003:284)

Johans kamp om att komma ur underläge har krönts med framgång. Den vuxne karaktären är "en efter omständigheterna lycklig man" som har gjort en riktig klassresa och fătt alla de förmåner han strävat efter (Flygt 2003:20). Underdogskänslan verkar dock infinna sig och genomsyrar den kritik av folkhemsvisionen som han formulerar. Man kan gissa att han också för fram kritiken å andras vägnar, nämligen de gamla vännerna från Borgmästargården, som han tidigare försökt avskärma sig från. Några av dem var i barndomen mycket mer utsatta än han själv, andra föll bort i skolans gallring, ett par blev missbrukare eller kriminella. En speciell grupp bland dessa underdogs är också personer som upprepade sina föräldrars fel som Johans egen syster Monika som gav upp i kampen om ett bättre liv.

\subsection{LOTTA}

Lotta Larsson är huvudpersonen i Var det bra så?, en berättelse om att växa upp i en storstadsförort på sjuttio-och åttiotalet. Romanen är också en polemik med den förenklade idylliska bilden av det mångkulturella samhället där de väsentliga problemen förbigås med tystnad och begreppet mångkultur 
ofta reduceras till nya smaker och dofter som berikar den svenska matkulturen (Samuelsson 2000).

Lottas föräldrar skilde sig när hon var fyra år gammal. Flickan bor med mamma och lillebror $i$ ett höghus $i$ den fiktiva invandrartäta stockholmsförorten Stensby som påminner om Tensta. Kontakten med fadern, som har flyttat och bildat en ny familj, är regelbunden men någon djupare relation utvecklas aldrig. Han verkar höra till en annan värld, där man köper varandra dyra julklappar, åker skidor i Alperna på vinterlovet och diskuterar vid julbordet om invandrare som säljer grönsaker på torget och är "älskvärda på ett nästan gammaldags sätt”, jämfört med kalla och hämmade svenska landsmän (Andersson 1999:107).

Eftersom romanen är berättad i tredje person och i flera avseenden påminner om socialreportage med personer som är representanter för grupper och bärare av idéer blir gränsen mellan barnets upplevelser och den kommentar som läggs till i vuxet perspektiv knappast möjlig att fastställa. Lotta presenteras i boken som en brådmogen flicka med en alltmer kritisk syn på den verklighet som omger henne. Hon tycks mycket tidigt ha blivit medveten om familjens sociala utsatthet: hennes kläder är köpta på rea på Tempo eller omsydda av gamla plagg och den billigaste maten som ofta inhandlas många gånger är av dålig kvalitet. (Andersson 1999:19) Pengarna räcker knappt och Lottas bror Jonas måste byta från ishockey till fotboll för modern har inte råd att skaffa dyr utrustning (Andersson 1999:105). Den ekonomiska aspekten är ett viktigt inslag i Lottas mindervärdeskomplex. Hon avundas sina kompisar vars mödrar alltid är eleganta och vars fäder går till jobbet i kostym och hon skäms för sin mamma som har börjat plugga engelska och lider av en hudsjukdom som orsakas av kemiska ämnen hon har kontakt med på sitt jobb. Skammen och besvikelsen är dock något hon inte visar öppet. På faderns fråga hur de har det hemma svarar hon alltid: "Vi har det bra. Jättebra" (Andersson 1999:109).

Det utanförskap som skildras i boken har också en tydligt markerad etnisk dimension. Lottas klass består till stor del av barn vars namn avslöjar deras icke-svenska ursprung. Infödda svenskar är i Stensby en minoritet bland många andra och Lotta inser att hon blir offer för den sociala segregationen på samma sätt som hennes skolkompisar med invandrarbakgrund. Som förortsbo och barn till en skild lågavlönad kvinna har hon en lika dålig start i livet som de andra barnen i Stensby.

Medvetenheten om att alla sitter i samma båt är dock knappast någon faktor som stärker gruppens solidaritet. Verbal och fysisk aggression är ett vanligt inslag i relationerna, eleverna bär på etniska fördomar och kallar varandra för "svennehora", "tattarballe" och "turkjävel". Den råa styrkan och den ekonomiska ställningen är andra faktorer som bestämmer den hackordning som uppstår. Därför får man en känsla att det snarare är ett antal utanförskap 
som skildras i Var det bra så? än en kollektiv upplevelse. Anna är adopterad från Asien och mobbas på grund av sitt utseende. Zeynap som kommer från Turkiet är kär i en helsvensk kille och gör sitt bästa för att visa att hon duger, hon delar hans rasistiska åsikter och vill bli så svensk som möjligt. Jocke äter havregrynsgröt varje morgon för att få hårda muskler och slippa betraktas som en glasögonprydd, klarinettspelande mes (Andersson 1999:151). Leyla från Libanon är för duktig och ambitiös för att anpassa sig till gruppen och hon får till sist byta skola.

Lottas inställning till kompisarna från Stensby är ganska komplicerad. Hon har svårt att knyta kontakter, tenderar att se ner på de andra samtidigt som hon vill vara med $\mathrm{i}$ gruppen. Det individuellt upplevda utanförskapet har i hennes fall sina rötter $\mathrm{i}$ övertygelsen om att hon duger till något mer och $\mathrm{i}$ hennes politiska medvetenhet. Medan Lottas mor fortfarande verkar hysa tilltro till den socialdemokratiska välfärdsberättelsen ser hennes dotter klyftan mellan politikernas löften och verkligheten. I sin bedömning av folkhemmet verkar hon dock vara ganska splittrad. Hon försvarar den stora visionen när den kritiseras av kompisar som inte är infödda svenskar och ifrågasätter den när hon pratar med mamma. Denna dubbla attityd tycks bottna i känslan av att hon själv inte får njuta av de förmåner som skulle garanteras alla barn i folkhemmet.

"Jag ska se till att aldrig få det som du", säger Lotta till sin mamma (Andersson 1999:24). Flickan verkar att hon har goda förutsättningar för att skaffa utbildning: hon är begåvad, har bästa betyg i skolan, tycker om att läsa. Hon letar lite på måfå efter ett mål i livet men när hon slutligen hittar något som intresserar henne blir hon avrådd av syo-konsulenten som anser att Lotta borde satsa på något mer realistiskt: "Det är ytterst få som blir filmrecensenter förstår du. Man måste plugga en massa år på universitet. (...) Och det är hemskt hård konkurrens. Hemskt hård.” (Andersson 1999:124) Detta är en knäck för Lottas redan dåliga självkänsla. Att hon inte får den uppmuntran och det stöd hon behöver resulterar $\mathrm{i}$ att hon inte längre vågar drömma om att hennes liv någon gång skulle kunna förändas. Samtalet med Laylas pappa är ett tydligt bevis på att hon redan vid starten har gett upp:

- Vad vill du bli, Lotta?

- Det vet jag inte.

- Men du måste väl ha några drömmar om vad du vill bli? Vad vill dina föräldrar att du ska bli? (...)

- Dom har inte sagt något särskilt om det.

- Men du har väl tänkt läsa på universitetet? (...)

- Universitetet är nog för svårt för mig. Det är hård konkurrens. Och det blir så mycket lån också som man får dras med sen.” (Andersson 1999:134-135) 
Bland de karaktärer som skildras i romanen har Layla varit den som haft största chanser att förverkliga sina framtidsplaner, tack vare föräldrarnas engagemang och beslutet att byta skola. Av den information om personernas fortsatta öden som kommer i bokens slut får vi veta att hon jobbar på TV där hon med fina ord berättar om den mångkulturella förorten där hon växt upp. Hennes gamla kompisar anser att hon har sålt sig. I deras fall har barndomen i Stensby inneburit att de blivit stämplade för livet. De har antingen misslyckats i sina försök att komma ur utanförskapet eller aldrig vidtagit några. Zeynap kör taxi, Anna är arbetslös och har tre barn med tre olika män, Micke har suttit i fängelse. Det enda som finns kvar av Lottas filmintresse är jobbet som biomaskinist. Vid bokens slut är hon 28 år gammal, desillusionerad, utan drömmar och framtidsplaner. Hon tycks sjunka ner i den passivitet som kännetecknar de flesta Stensbybor och ha funnit sig i att hon tillhör förlorarskaran. (Andersson 1999:163)

\section{STYVBARNEN I FOLKHEMMET}

I alla fem analyserade barndomsskildringar är utanförskap ett av de centrala problem som berättelserna är uppbyggda kring. Känslan av att vara avvikande, bortglömd, oönskad påverkar processen att forma barnens identitet. Erfarenheter av utestängning eller utfrysning bidrar till att befästa mindervärdeskomplex vilket gör starten i det vuxna livet ytterst svår och minskar chanserna att uppnå drömmar och mål.

Om man jämför de barn som är huvudkaraktärer i romanerna lägger man märke till både likheter och skillnader. Deras utanförskap har ofta sina rötter i tillhörigheten i en marginaliserad grupp som tornedalingar, invandrare eller förortsbor och den kollektiva dimensionen markeras i böckerna trots att själva upplevelsen av att stå utanför är mer av individuell karaktär. I den önskan att få vara som de andra och omfattas av den trygghet som gemenskapen ger som uttrycks av alla huvudkaraktärerna kan man identifiera inslag av avundsjuka på dem som har fått det bättre i livet. Mycket tydligt ses detta hos Johan och Lotta, i mindre omfattning också hos Leena. Insikten om att "inget kommer att ges en till skänks" (Flygt 2003:167) resulterar i att olika strategier att klara sig i tillvaron utvecklas. I Johans fall blir det en kombination av underordning och revanschlusta, han försöker att inte låta sig domineras av negativa känslor som bottnar i skräck och utsatthet utan bevisa att han duger. En liknande attityd återfinner vi hos Juha som efter sina misslyckade anpassningsförsök väljer en outsiders väg och distanserar sig från sina plågoandar. Lotta är de bådas motsats. Efter att ha tappat alla sina illusioner ger hon upp och sjunker ner i apati. 
Solidaritetsgraden mellan de utsatta varierar från roman till roman. Umgänget med vänner som i flera avseenden delar hennes utanförskap ger Leena det stöd hon behöver för att kunna uthärda. Mattis utgångsläge är utan tvekan bättre än Niilas men de två utvecklar en vänskap på lika villkor som bygger på förståelse och ömsesidigt förtroende. Juhas balansgång mellan de starka och de svaga i klassen slutar med att han, delvis motvilligt, får ansluta sig till de senare vars parti han senare tar i sin vuxna uppgörelse med barndomens spöken. Johan saknar nära vänner bland sina jämnåriga från Borgmästargården - upptagen med sin egen kamp om att överleva verkar han helt likgiltig inför deras problem precis som de är inför hans. Bristen på solidaritet präglar Lottas mångkulturella uppväxtmiljö, där barnen tar efter de vuxna och blir bärare av sociala och etniska stereotyper.

Fattigdom, familjevåld och missbruk är problem och motiv som återkommer i barndoms- och ungdomsskildringar som författas i olika länder och kulturer. Konkurrens inom gruppen och krav som ställs på dem som får vara med samt mobbning av de svaga och missanpassade är företeelser som uppmärksammas i talrika sociologiska och pedagogiska analyser av skolan och andra ungdomsmiljöer. Med tanke på det skulle man kunna formulera slutsatsen att det är ett universellt budskap som förmedlas i de fem analyserade svenska romanerna och man behöver inte nödvändigtvis folkhemmets väggar som referensram för att nå fram till läsarna. Juhas historia kan tolkas som individens kamp om att behålla sin integritet och inte slukas av det dominerande kollektivet, Leenas som en dramatisk skildring av missbrukarbarnets erfarenheter av uppväxt under ogynnsamma förhållanden. Förortsbarnen Johan och Lotta är underdogs som med olika framgång försöker klättra upp i samhällshierarkin och Matti får symbolisera en ung provinsbos längtan efter den vida världen. Populärmusik från Vittula kan dessutom uppfattas - av både svenska och utländska läsare som en tornedalsk skröna med lockande exotiska inslag och vid en sådan läsning träder karaktärernas utanförskap i bakgrunden.

Svaret på frågan som jag ställt i inledningen är dock knappast entydigt. Romanerna är, som jag vid flera tillfällen påpekat, starkt förankrade $\mathrm{i}$ den folkhemska vardagen och författarna anknyter i sina försök att skapa de för svenska läsare igenkännbara samhälleliga ramarna för den berättade historien till de etablerade berättelserna om välfärdsstadens uppkomst, blomstringstid och kris. Huvudpersonerna som är födda på 1960- och 1970-talen har växt upp med bilden av det goda hemmet där alla trivs och har samma chanser att utveckla sig som en viktig referenspunkt. Den bilden har de ärvt av sina föräldrar som föddes på 1930- och 1940-talen och hörde till den första generationen av folkhemsbarn vilka kom att omfattas av alla nyinförda sociala 
förmåner, men också efter sina far-och morföräldrar som var med om när det nya efterträdde det gamla. ${ }^{13}$ Detta gäller även för Leena, vars föräldrar är invandrare från Finland och nykomlingar $\mathrm{i}$ folkhemmet men deras föreställningar om Sverige är ännu mer idealiserade och förväntningarna på det goda landet tycks ännu större än svenska fyrtiotalisters.

Matti, Leena, Juha, Johan och Lotta blir redan under sin barndom medvetna om att alla löften inte har blivit förverkligade när de deltar i sina föräldrars materiella bekymmer och inser att samhället är skiktat, vissa privilegier är knutna till social ställning och bakgrunden determinerar ens framtidsperspektiv. De får också erfara en baksida av det moderna projektet, nämligen den tvångsmässiga uniformeringen av dem som tas in $\mathrm{i}$ gemenskapen. Under deras uppväxttid följer en pågående devalvering av folkhemstanken som försiggår parallellt med den ekonomiska krisen. Detta resulterar i att alla huvudkaraktärerna utvecklar en kritisk syn och deras tilltro till politikerna är inte längre så självklar och villkorslös. Och när de har kommit upp i vuxenålder sammanfaller detta med början av debatten om folkhemmets kris, bruten gemenskap och utanförskapets utbredning.

Varje form av utanförskap som skildras i romanerna är ett konglomerat av skilda faktorer, både yttre och inre, men gemensamt för karaktärerna är besvikelsen över den stora socialdemokratiska visionen. Denna besvikelse artikuleras tydligare ju mer det retrospektiva, vuxna perspektivet framträder i romanerna. Matti, Leena, Juha, Johan och Lotta kan kallas för inkarnationer av den kategori medborgare som inte skulle finnas i det lyckliga folkhemmet. De är folkhemmets styvbarn som har hamnat i gemenskapens utkanter och berövats de förmåner som borde garanteras alla. Det specifikt svenska i de fem analyserade skildringarna ligger också $\mathrm{i}$ att diskussionen om utanförskap lätt kan förflyttas från ett personligt till ett allmänt plan. Barnkaraktärer är starkt individualiserade men de kan också betraktas som representanter för grupper som får stå utanför det till synes perfekta svenska samhället.

\section{LITTERATURFÖRTECKNING}

\section{ANALYSMATERIAL}

Alakoski, Susanna. 2007. Svinalängorna. Stockholm: Bonnier. Andersson, Lena. 1999. Var det bra så?. Stockholm: Natur och Kultur. Flygt, Torbjörn. 2003. Underdog. Stockholm: Norstedt.

13 Den klassiska socialdemokratiska berättelsen om övergången från Fattigsverige till det moderna projektet (Wiklund, 2006:11-12; Mithrander, 2002: 54) är viktig referensram i romanerna. Berättelsen kan kännas igen i beskrivningar av asfalteringen av Vittula (Niemi, 2002:14), Moilanens glädje över den splitternya lägenheten med alla moderna bekvämligheter (Alakoski, 2007: 21) eller analyser av fluortantens roll i att "borsta bort sitt ursprung, dess dåliga andedräkt" som görs av berättaren i Underdog. (Flygt, 2003: 127). 
Gardell, Jonas. 1992. En komikers uppväxt. Stockholm: Norstedt.

Niemi, Mikael. 2000. Populärmusik från Vittula. Stockholm: PAN Norstedt.

\section{OVRIGA KÄLLOR}

Augustpriset. Tillgänglig på http://augustpriset.se/

Berggren Henrik \& Lars Trägårdh 2006. Är svensken människa? Gemenskap och oberoende i det moderna Sverige. Stockholm: Norstedts.

Czykwin, Elżbieta. 2007. Stygmat społeczny. Warszawa: Wydawnictwo Naukowe PWN.

Davidsson Tobias. 2010. Utanförskapelsen. En diskursanalys av hur begreppet utanförskap artikulerades i den svenska riksdagsdebatten 2003-2006, Socialvetenskaplig tidskrift. 2010:2, s. 149-169. Tillgänglig på: http://www.socwork.gu.se/kontaktaoss/Personlig hemsida/tobias-davidsson/

Hansson Per Albin. 1982. Folkhemmet, medborgarhemmet. Per Albin Hanssons tal i andra kammarens remissdebatt, 1928. I: Från Fram till folkhemmet: Per Albin Hansson som tidningsman och talare / urval och inl. av Anna Lisa Berkling. Solna: Metodica Press.

Hägg Göran, 2006. Välfärdssåren. Svensk historia 1945-1886. Stockholm: Månpocket.

Ljungqvist, Pernilla \& Sofia Hirsch. 2009. Utanförskap i barngruppen. Vikten av samspel och gemenskap. Examensarbete i Lärarprogrammet vid Institutionen för pedagogik. Tillgänglig på: http://bada.hb.se/handle/2320/4994

Löfvendahl, Erik. 2006. Livet hos de till synes chanslösa, Svenska Dagbladet 24.03.

Mikael Niemi. Författarpresentation på Norstedts webblats. Tillgänglig på http://www.norstedts.se/ Forfattare/Alfabetiskt/N/Mikael-Niemi/

Mithrander, Conny. 2002. Från Mönsterland till Monsterland. Folkhemska berättelser. I: Bergvall, Åke, Yvonne Leffer \& Conny Mithrander (red.). Berättelser i förvandling berättande $i$ ett intermedialt och tvärvetenskapligt perspektiv. Karlstad: Karlstad University Studies 2002:12, s. 53-85.

Stråth, Bo 1992. Folkhemmet mot Europa. Ett historiskt perspektiv på 90-talet. Stockholm: Tiden.

Szarfenberg, Ryszard. 2008. Pojęcie wykluczenia społecznego. I: Duda, Małgorzata \& Bożena Gulla (red.) Przeciw wykluczeniu spotecznemu. Kraków: Wydawnictwo Naukowe PAT

Wiklund, Martin. 2006. I det modernas landskap. Historisk orientering och kritiska berättelser om det moderna Sverige mellan 1960 och 1990. Stockholm / Stenhag: Brutus Östlings Bokförlag Symposion.

Utanförskapets karta. En kartläggning över utanförskapet i Sverige. 2004. Folkpartiets rapport (2004-12-05). Tillgänglig på:http://www.folkpartiet.se/upload/25383/Utanf\%C3\%B6r skapets\%20karta\%202004.pdf

\section{Magdalena Żmuda-Trzebiatowska}

Uniwersytet im. Adama Mickiewicza w Poznaniu

Katedra Skandynawistyki

Collegium Novum

al. Niepodległości 4

61-874 Poznań

Poland

magdazt@amu.edu.pl 